\title{
Analysis of Gene Expression in Two Growth States of Xylella fastidiosa and Its Relationship with Pathogenicity
}

\author{
Alessandra A. de Souza, ${ }^{1,2}$ Marco A. Takita, ${ }^{2}$ Helvécio D. Coletta-Filho, ${ }^{2}$ Camila Caldana, ${ }^{2}$ Gustavo H. \\ Goldman, ${ }^{3}$ Giane M. Yanai, ${ }^{4}$ Nair H. Muto, ${ }^{4}$ Regina C. de Oliveira,${ }^{4}$ Luiz R. Nunes, ${ }^{4}$ and Marcos A. \\ Machado $^{2}$ \\ ${ }^{1}$ Empresa Brasileira de Pesquisa Agropecuária-EMBRAPA; ${ }^{2}$ Centro APTA Citros 'Sylvio Moreira'/Instituto Agronômico-CP \\ 04, CEP 13490-970, Cordeirópolis-SP, Brazil; ${ }^{3}$ Faculdade de Ciências Farmacêuticas de Ribeirão Preto-Universidade de \\ São Paulo. Av. do Café S/N, CEP 14040-903, Ribeirão Preto-SP, Brazil; ' Núcleo Integrado de Biotecnologia-Universidade \\ de Mogi das Cruzes. Av. Dr. Candido Xavier de Almeida e Souza, 200. CEP 08780-911, Mogi das Cruces-SP, Brazil.
}

Submitted 24 December 2002. Accepted 24 June 2003.

Xylella fastidiosa is a plant pathogen responsible for diseases of economically important crops. Although there is considerable disagreement about its mechanism of pathogenicity, blockage of the vessels is one of the most accepted hypotheses. Loss of virulence by this bacterium was observed after serial passages in axenic culture. To confirm the loss of pathogenicity of $X$. fastidiosa, the causing agent of citrus variegated chlorosis (CVC), freshly-isolated bacteria (first passage [FP]condition) as well as bacteria obtained after 46 passages in axenic culture (several passage [SP]condition) were inoculated into sweet orange and periwinkle plants. Using real time quantitative polymerase chain reaction, we verified that the colonization of FP cells was more efficient for both hosts. The sequence of the complete $X$. fastidiosa genome allowed the construction of a DNA microarray that was used to investigate the total changes in gene expression associated with the FP condition. Most genes found to be induced in the FP condition were associated with adhesion and probably with adaptation to the host environment. This report represents the first study of the transcriptome of this pathogen, which has recently gained more importance, since the genome of several strains has been either partially or entirely sequenced.

Xylella fastidiosa is a gram-negative and xylem-inhabiting bacterium responsible for diseases of economically important crops such as plum, almond, peach, coffee, grapevine, and citrus (Lima et al. 1998, Purcell and Hopkins 1996) as well as ornamental plants (Barnard et al. 1998). In Brazil, it is responsible for citrus variegated chlorosis (CVC), a disease that causes annual losses of about $\$ 100$ million to the citrus agroindustry. For this reason, a Brazilian consortium sequenced the genome of the CVC strain 9a5c of $X$. fastidiosa, which became the first plant pathogen to have its complete genome sequenced (Simpson et al. 2000).

There is considerable disagreement about the mechanisms of pathogenicity of $X$. fastidiosa. However, the vascular occlusion by bacterial aggregates and the production of extracellular polysaccharides (EPS) leading to water stress is the most accepted cause of the disease (Machado et al. 2001). The high

Corresponding author: Marcos Antonio Machado; Telephone and Fax: (55)(19) 3546-1399; E-mail: marcos@ centrodecitricultura.br. water stress observed in leaves affected with CVC is characterized by a drastic decrease in the water potential, inducing leaf wilting even in plants grown in humid soil. The water deficiency symptoms of CVC-affected plants occur due to the increase in the water flow resistance throughout the xylem vessels (Machado et al. 1994). Ultrastructural studies of X. fastidiosa strains in xylem vessels showed cellular aggregates immersed in an electron-dense region probably composed by EPS (Chagas et al. 1992). Aggregated colonies appeared to be attached to the xylem vessels by extracellular strands produced by the bacteria, which seemed to be related to pathogenicity.

Hopkins (1985) observed that virulent strains of X. fastidiosa causing Pierce's disease (PD) could partially or totally lose their virulence after successive transfers in culture medium. The cells also lost their aggregation ability, suggesting that there may be a connection between aggregation and pathogenicity of $X$. fastidiosa. A similar observation was made for the CVC strain inoculated into periwinkle (Catharanthus roseus), an alternative host. Inoculation with cells at the eighth transfer in culture medium was able to infect a greater number of plants and induce symptoms faster than inoculation using cells at the 58th passage (Monteiro et al. 2001).

Loss of virulence after several passages in axenic culture in either solid or liquid medium is observed in several pathogenic bacteria with wide host spectrum (Behr et al. 1999; Hu et al. 1991; Levine et al. 1990; McCutchan et al. 1976; Somerville et al. 2002). The major biological property lost in avirulent strains after several passages was the ability to attach to tissues (Masuzawa et al. 1994). We quantified the ability of X. fastidiosa to colonize sweet orange (Citrus sinensis L. Osb.) and periwinkle plants after being exposed to both growth conditions by real time quantitative polymerase chain reaction (qPCR).

We hypothesize that the loss of the aggregation ability of $X$. fastidiosa after several passages in culture medium is associated with suppression of gene expression and that the reactivation of these genes might be slow or no longer attained, which could be reflected in the delay or absence of symptom development. This led us to start a comparative study, using microarray technology, of the gene expression profiles upon first passage in culture and after serial subcultures, opening the possibility of identifying genes associated with pathogenicity.

This report represents the first transcriptome study of this bacterial pathogen that has recently gained more importance 
since the entire genome of isolates from citrus (Simpson et al. 2000) and grape (ONSA website) have been completely sequenced and those of almond and oleander strains (U.S. Department of Energy microbial genomics webpage) have been partially sequenced.

\section{RESULTS}

\section{Concentration of $X$. fastidiosa}

in plant tissue, estimated by real time qPCR.

The ability of $X$. fastidiosa to colonize plant tissues was estimated by determining the number of bacterial cells in infected tissues using qPCR. For the standard curve, serial dilutions of $X$. fastidiosa DNA, ranging from 100,000 to 1 estimated copy number, were done and used as template for the analyses (Fig. 1). "Threshold cycle" $\left(C_{T}\right)$ values increased in each dilution, ranging from 23.35 to 40 cycles. Therefore, under the PCR conditions tested, the quantification was shown to be linear from 100 to 100,000 initial copies of template DNA per reaction. The straight line calculated by logarithmic regression is represented by the equation $y=-4.12972 \times \operatorname{Ln}$ (number of copies) +44.397 , with $\mathrm{R}^{2}=0.9975$. Samples with a fluorescent signal above a preset threshold $\left(\mathrm{C}_{\mathrm{T}}<36.29\right)$ after 40 PCR cycles were considered positive, which corresponds to $>100$

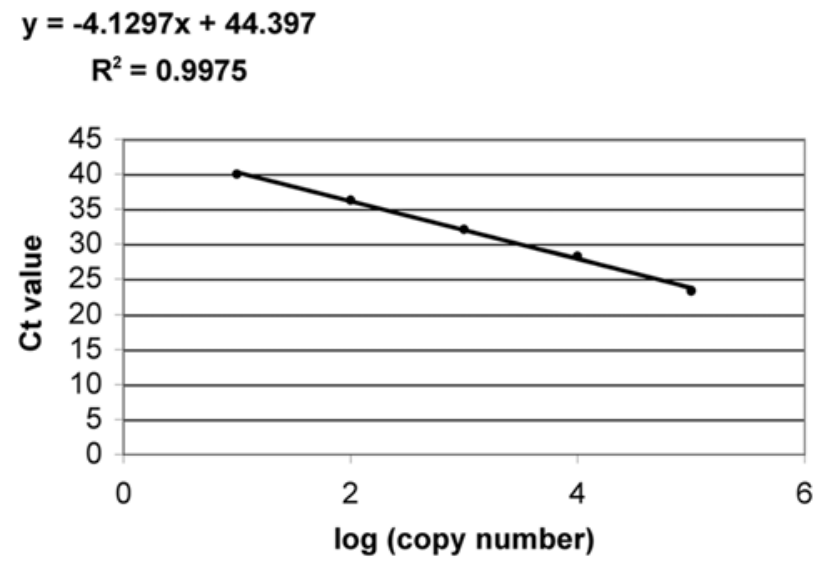

Fig. 1. Standard curve of Xylella fastidiosa cells determined by real-time quantitative polymerase chain reaction $(\mathrm{PCR}) . \mathrm{C}_{\mathrm{T}}$ is plotted against the $\log$ number of $X$. fastidiosa cells in samples of 10 -fold dilutions of template DNA (only one template per cell). The straight line calculated by logarithmic regression was $y=-4.12972 \times \mathrm{Ln}$ (number of copies) + 44.397, with $\mathrm{R}^{2}=0.9975$. The samples with an increase of fluorescent signal above a present threshold within 40 PCR cycles were considered positive when $C_{T}$ values were lower than 36.29 , which corresponds to $>100$ initial copies of template. initial copies of template. The high value of $\mathrm{R}^{2}$, obtained for the standard curve, and the good reproducibility of the repetitions within each point of the serial dilution of the DNA confirm the validity of the assay for the quantification of the target DNA.

The estimated populations of $X$. fastidiosa in plant tissues are shown in Table 1. Three measurements of a single DNA sample were carried out. The percentage of coefficient variation $(\mathrm{CV} \%)$ of the intrameasures ranged from 0.00 to $2.91 \%$, with an overall average of $0.82 \%$ (data not shown). Intermeasures of the $\mathrm{C}_{\mathrm{T}}$ values (mean of 10 plants) showed a CV\% ranging from 0.18 to $18 \%$. However, values of $\mathrm{C}_{\mathrm{T}}$ from either citrus or periwinkle inoculated with $X$. fastidiosa grown under several passage (SP) and first passage (FP) conditions were significantly different $(P<0.001$, according to analysis of $t$ test). The average of $\mathrm{C}_{\mathrm{T}}$ for both plant species was always lower when cells of the FP condition were used for the inoculation (lower $\mathrm{C}_{\mathrm{T}}$, more template). For both hosts, the population of $X$. fastidiosa in FP conditions kept increasing for 60 to 180 days, reaching $3.9 \times 10^{4}$ (sweet orange) and $7.7 \times 10^{4}$ (periwinkle) DNA copies per reaction. In contrast, SP bacterial populations increased for only 120 days reaching $0.9 \times 10^{3}$ (sweet orange) and $2.6 \times 10^{3}$ (periwinkle) DNA copies per reaction and then declined after 180 days. The concentration of $X$. fastidios $a$ on periwinkle was always higher than in sweet orange for both growth conditions. Development of symptoms was observed only in sweet orange and periwinkle plants inoculated with cells from the FP condition, which is in agreement with the number of cells present in the plants.

Construction of $X$. fastidiosa DNA microarray and analysis.

We constructed DNA microarrays carrying representative sequences from approximately 2,200 open reading frames (ORF) from the genome of $X$. fastidiosa strain 9a5c. Total RNA obtained from cells grown under FP and SP conditions was labeled and used in a competitive hybridization. The data obtained from the experiments (published as supporting information on the Centro APTA Citros website) were used for statistical analyses with SAM (significance analysis of microarrays), which calculated the fold change and the significance of the differences in expression. SAM calculates the fold change in gene expression level by the ratio of average fluorescent intensity for each condition. The fold change cutoff used in the analysis was 2.0 , together with $\Delta 0.40469$ and 1,000 permutations. These parameters resulted in a false significant number (FSN) of 0.79 and a false discovery rate (FDR) of less than $2 \%$, meaning that less than one so-called statistically significant ORF could be a false positive in our experiment. To increase confidence, we have picked only ORFs that showed a

Table 1. Summary of results of real-time polymerase chain reaction detection of Xylella fastidiosa in citrus and periwinkle plants ${ }^{\mathrm{a}}$

\begin{tabular}{|c|c|c|c|c|c|c|c|c|c|c|c|c|}
\hline \multirow[b]{2}{*}{ Inoculum } & \multicolumn{4}{|c|}{60 dai $^{b}$} & \multicolumn{4}{|c|}{120 dai } & \multicolumn{4}{|c|}{180 dai } \\
\hline & $\mathbf{C}_{\mathrm{T}}^{\mathrm{c}}$ & SD & $\mathrm{CV} \%$ & Copy no. ${ }^{d}$ & $\mathbf{C}_{\mathbf{T}}$ & SD & $\mathrm{CV} \%$ & Copy no. & $\mathbf{C}_{\mathbf{T}}$ & SD & $\mathrm{CV} \%$ & Copy no. \\
\hline \multicolumn{13}{|l|}{ Citrus } \\
\hline SP & 39.98 & 0.07 & 0.18 & $\mathrm{ND}^{\mathrm{e}}$ & 32.64 & 1.28 & 3.81 & 88 & 40.00 & 0.00 & 0.00 & ND \\
\hline $\begin{array}{l}\text { FP } \\
t \text { test }^{\mathrm{f}}\end{array}$ & $\begin{array}{c}34.18 \\
0.0001\end{array}$ & 1.96 & 5.51 & 532 & $\begin{array}{c}30.61 \\
0.006\end{array}$ & 3.37 & 10.50 & 1,035 & $\begin{array}{l}30.2 \\
0.004\end{array}$ & 5.59 & 18.00 & 39,775 \\
\hline \multicolumn{13}{|l|}{ Periwinkle } \\
\hline SP & 32.55 & 0.81 & 2.40 & 827 & 31.59 & 2.65 & 8.21 & 2,635 & 34.97 & 0.67 & 1.80 & 200 \\
\hline $\begin{array}{l}\mathrm{FP} \\
t \text { test }\end{array}$ & $\begin{array}{c}28.74 \\
0.0001\end{array}$ & 1.03 & 3.46 & 6,218 & $\begin{array}{l}27.77 \\
0.0003\end{array}$ & 2.44 & 8.30 & 10,158 & $\begin{array}{r}25.97 \\
0.0001\end{array}$ & 4.45 & 16.63 & 77,700 \\
\hline
\end{tabular}

${ }^{a}$ Citrus and periwinkle plants were inoculated with $X$. fastidiosa grown under several passage (SP) and first passage (FP) conditions.

${ }^{\mathrm{b}}$ dai $=$ days after inoculation.

c Average of 10 plants.

${ }^{\mathrm{d}}$ Copy number of DNA estimated from $\mathrm{C}_{\mathrm{T}}$ values

e ND = Not determined, below detection limit (less than 100 cells).

${ }^{\mathrm{f}}$ Statistical $t$ test between samples from SP and FP conditions. 
significant difference in expression in both $\mathrm{Cy} 3$ and $\mathrm{Cy} 5$ labeling (in independent SAM analyses) and displayed an average background-subtracted fluorescent intensity above 500 units, since control experiments showed that weaker signals were likely to produce unreliable results (data not shown). To verify whether specific $X$. fastidiosa sequences could be associated with preferential incorporation of one fluorophore, DNA from the 9a5c strain was labeled with Cy3-dCTP and Cy5-dCTP in two separate reactions, and equimolecular amounts of the labeled DNAs were mixed and hybridized to a microarray. Two independent hybridizations were performed (in triplicate), and the results showed that all spots provided similar hybridization intensities with both fluorophores. SAM analysis was performed on the data obtained from these experiments, returning no significant changes (Costa de Oliveira et al. 2002). Similar results were obtained using labeled cDNA derived from total RNA from $X$. fastidiosa cells grown in liquid Periwinkle wilt (PW) medium (data not shown). No fluorescence was observed in the chip when the total RNA was labeled using Klenow, showing absence of DNA in the total RNA preparation (data not shown).

The induction or repression of the genes is shown in a scatter plot (Fig. 2). Expression levels for the majority of genes did not differ between the growth conditions. Of this subset, 18 genes showed a statistically significant increase in the levels of transcripts, while 21 genes were repressed in the FP condition. The genes differentially expressed are distributed throughout the different categories, as summarized in Table 2. It is important to mention that the function of genes was assigned only by homology with proteins from other organisms, since no gene from $X$. fastidiosa has been functionally characterized so far.

Many of the differentially expressed genes encode hypothetical proteins, reflecting the large number of ORFs encoding unknown proteins found in the genome of $X$. fastidiosa and housekeeping genes. Interestingly, genes potentially involved in pathogenicity, virulence, and adaptation were induced only in the FP condition.

\section{Induction of genes in the FP condition encoding pathogenicity-related proteins.}

Seven genes encoding pathogenicity-related proteins are expressed mainly in the FP condition. Three of these genes are related to adhesion in other organisms. They encode a putative fimbrial protein similar to the FimA precursor of Xanthomonas hyacinthi and two nonpili adhesins similar to UspA1 from Moraxella catharralis and Hsf from Haemofilus influenzae. Although the ratio for the msrA gene is below the cutoff limit, its higher expression in the FP condition is worth mentioning,

Table 2. Expression ratio of functional groups of genes in first passage (FP) condition

\begin{tabular}{|c|c|c|c|c|}
\hline Functional group $^{a}$ & Gene $^{\mathbf{a}}$ & ORF number ${ }^{a}$ & Description & Ratio of gene expression ${ }^{b}$ \\
\hline \multirow[t]{5}{*}{ Intermediary metabolism } & orf 111 & XF0357 & Esterase & 3.17 \\
\hline & orf 111 & XF2151 & Esterase & 2.74 \\
\hline & AF0343 & XF1133 & Tryptophan repressor binding protein & -2.01 \\
\hline & korA & $\mathrm{XFa} 0057$ & Transcriptional regulator & -2.23 \\
\hline & $g l o \mathrm{~A}$ & XF1399 & Lactoylglutathione lyase & -2.07 \\
\hline \multirow[t]{3}{*}{ Biosynthesis of small molecules } & $\mathrm{SCH} 10.14 \mathrm{c}$ & XF0356 & Cytochrome P-450 hydroxylase & 2.17 \\
\hline & orfU1 & XF1441 & Phosphohydrolase & -3.65 \\
\hline & folC & XF1946 & Folylpolyglutamate synthase dihydrofolate synthase & -2.38 \\
\hline \multirow[t]{4}{*}{ Macromolecule metabolism } & pros & XF0445 & Prolyl-tRNA synthetase & 2.02 \\
\hline & $\operatorname{magI}$ & XF1326 & DNA-3-methyladenine glycosidase & -3.51 \\
\hline & $\operatorname{mia} \mathrm{A}$ & XF0090 & $\begin{array}{l}\text { tRNA delta(2)-isopentenylpyrophosphate transferase } \\
(35.5 \mathrm{kDa})\end{array}$ & -2.12 \\
\hline & $\operatorname{traC}$ & XF2025 & DNA primase & -2.02 \\
\hline \multirow[t]{3}{*}{ Cell structure } & lyc & XF2392 & Autolytic lysozyme & 2.23 \\
\hline & $\operatorname{trb} \mathrm{E}$ & XF2053 & Conjugal transfer protein & -2.16 \\
\hline & $d m t$ & XF0612 & Dolichol-phosphate mannosyltransferase & -2.94 \\
\hline \multirow[t]{2}{*}{ Cellular process } & ape 2426 & XF1398 & $\mathrm{Na}^{+} / \mathrm{H}^{+}$exchange protein & -2.17 \\
\hline & $\sec \mathrm{B}$ & XF1801 & Protein-export protein & -2.64 \\
\hline \multirow{8}{*}{$\begin{array}{l}\text { Pathogenicity, virulence, } \\
\text { and adaptation }\end{array}$} & & & & \\
\hline & $\operatorname{fim} \mathrm{A}$ & XF2539 & Fimbrial protein & 2.20 \\
\hline & $m s r \mathrm{~A}$ & XF1940 & Peptide methionine sulfoxide reductase & 1.76 \\
\hline & uspA1 & XF1516 & Surface-exposed outer membrane protein & 10.15 \\
\hline & $h s f$ & XF1529 & Surface protein & 3.68 \\
\hline & $c v a \mathrm{C}$ & XF0263 & Colicin V precursor & 6.51 \\
\hline & acrA & XF2093 & Precursor of drug resistance protein & 2.07 \\
\hline & $x p s \mathrm{E}$ & XF1517 & General secretory pathway protein $\mathrm{E}$ & 2.00 \\
\hline \multirow[t]{15}{*}{ Hypothetical protein } & $\ldots$ & XF1255 & $\ldots$ & 8.04 \\
\hline & $\ldots$ & XF0531 & $\ldots$ & 8.18 \\
\hline & $\ldots$ & XF2076 & $\ldots$ & 2.83 \\
\hline & $\ldots$ & XF1434 & $\ldots$ & 2.55 \\
\hline & $\ldots$ & XF0265 & $\ldots$ & 2.06 \\
\hline & $\ldots$ & XF2662 & $\ldots$ & 3.57 \\
\hline & $\ldots$ & $X F 2252-53-54^{c}$ & $\ldots$ & -2.42 \\
\hline & $\ldots$ & XF1853 & $\ldots$ & -2.36 \\
\hline & $\ldots$ & XF0544-45-46 & $\ldots$ & -2.05 \\
\hline & $\ldots$ & XF1307 & $\ldots$ & -2.29 \\
\hline & $\ldots$ & XF1792 & $\ldots$ & -2.23 \\
\hline & $\ldots$ & XF2317 & $\ldots$ & -2.45 \\
\hline & $\ldots$ & XF0583 & $\ldots$ & -5.50 \\
\hline & $\ldots$ & XF1417 & $\ldots$ & -2.11 \\
\hline & $\ldots$ & XF2720 & $\ldots$ & -2.25 \\
\hline
\end{tabular}

\footnotetext{
${ }^{a}$ Based on AEG's Xylella fastidiosa genome project.

${ }^{\mathrm{b}}$ Positive and negative values represent induction and repression in FP condition, respectively.

${ }^{c}$ This pair of primers covers three ORFs.
} 
since the MsrA protein is important for the maintenance of adhesion in pathogenic bacteria (Wizemann et al. 1996).

Two other genes identified in our analysis are involved in adaptation to the environment. One of these genes encodes a protein with similarity to Colicin $\mathrm{V}$ in its $\mathrm{C}$-terminal portion, while the other one is homologous to acrA, a multidrug, resistance-protein encoding gene. Pfam analysis indicates that it belongs to the HlyD secretion protein family. The acr $\mathrm{B}$ gene located downstream of $a c r \mathrm{~A}$ also showed a significant higher expression in FP, although with a fold change less than 2 .

The last gene possibly involved in pathogenicity is $x p s \mathrm{E}$. This ORF encodes one of the components of the type II secretion system (general secretory pathway) that is responsible for secretion of degrading enzymes and toxins.

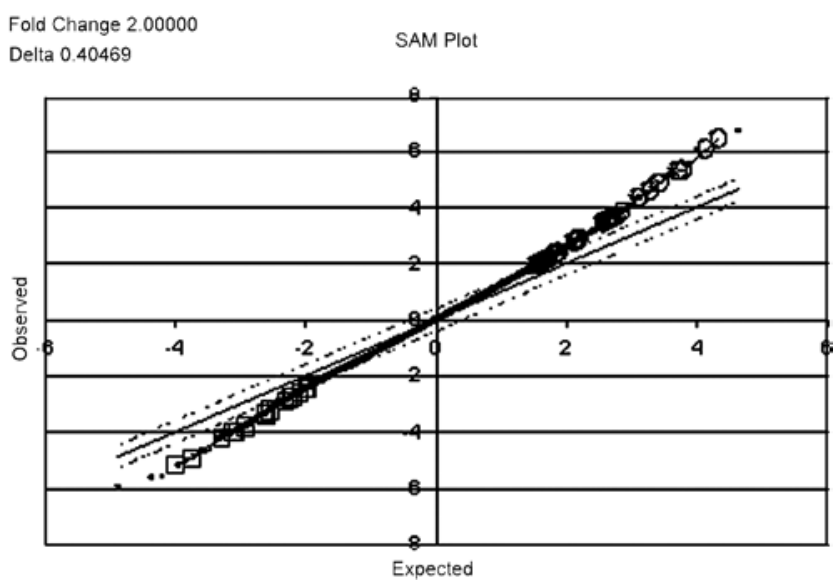

Fig. 2. Identification of genes with significant changes in expression. Scatter plot of the observed relative difference vs. the expected relative difference calculated by significance analysis of microarrays. The dashed lines indicate the cutoff for twofold induction and repression. The potentially significant induced or repressed genes for $\Delta=0.40469$ are represented by $\bigcirc$ and $\square$, respectively.
Confirmation of microarray data with reverse transcription (RT)-PCR analysis.

In order to validate the results from the microarray study, we performed RT-PCR analysis for the fimA, msrA, uspA1, hsf, $c v a \mathrm{C}$, acrA, and $x p s \mathrm{E}$ genes (Fig. 3). For these genes, expression ratios obtained in the microarray analysis were consistent with the RT-PCR ratios (Table 2, Fig. 3A), even though the data from the RT-PCR results from a single experiment, while in microarray analysis, the expression ratio for each transcript was calculated from the average expression ratios based on multiple measurements.

The ratios observed in the experiment in planta for all seven genes were different from those obtained for the condition utilized in the microarray. This difference was mainly observed for the msrA gene, which did not show any expression, even after 35 amplification cycles. All other genes showed a ratio between 1.27 and 1.70; nevertheless, as obtained in the microarray experiment, induction was always observed for the FP cells (Table 2, Fig. 3B).

\section{DISCUSSION}

$X$. fastidiosa cells grown under the SP condition were transferred in culture for one year, resulting in 46 passages. In this growth condition, $X$. fastidiosa and other microorganisms lose virulence or exhibit a significant reduction of it. Focusing on the virulence of $X$. fastidiosa, we used real-time PCR for quantification of bacteria within the xylem vessel. Calibration experiments using known amounts of $X$. fastidiosa DNA demonstrated that the detection was possible for $\mathrm{C}_{\mathrm{T}}$ values less than 36.29 , which is equivalent to 100 cells (Fig. 1). Intrameasure reproducibility among replications from the same DNA source was high (mean CV of $0.82 \%$ ). Even though intermeasures showed CV\% of 18 , the statistical difference between the treatments inoculated with FP and SP conditions of the bacteria was significant in Student $t$ test (Table 1). Cells of $X$. fastidiosa grown under the FP condition had greater ability to colonize plant tissue than those grown under the SP condition in all the
A

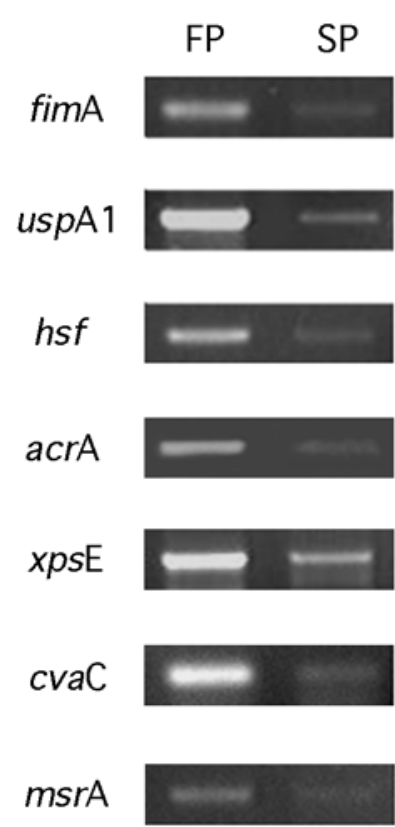

Quantitation ratio $\mathrm{FP} / \mathrm{SP}$
B

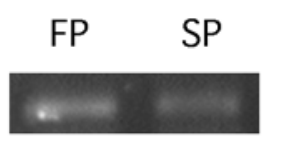

Quantitation ratio

$\mathrm{FP} / \mathrm{SP}$

1.34

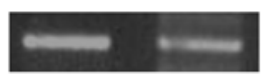

1.27

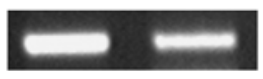

1.55

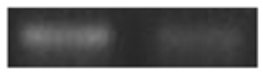

1.70

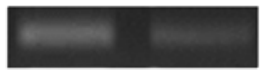

1.50

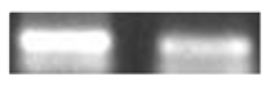

1.57

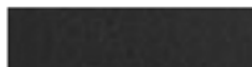

nd

Fig. 3. Reverse transcription-polymerase chain reaction of first passage (FP)-induced genes encoding pathogenicity factors in Xylella fastidiosa. The ratios of the normalized quantitated band densities are presented as the FP value divided by the several passage (SP) value. A, Experiment using the condition utilized in the microarray experiment. B, Experiment in planta, evaluated 15 days after inoculation. $\mathrm{nd}=$ not determined. 
evaluated points. The growth condition seems to affect multiplication and, consequently the movement within the hosts. This effect was more evident in the treatments with SP cells when a significant decrease of cell number, $15 \mathrm{~cm}$ above the inoculation point, was observed 180 days after inoculation (dai). On the other hand, a significant increase was observed in treatments with FP cells (Table 1). The more efficient colonization of FP cells within the plants allows development of symptoms in both sweet orange and periwinkle hosts. Conversely, symptoms were not observed in either plant species inoculated with SP cells, probably due to the low cell number observed in these plants, which could be insufficient for obstructing vessels. Vascular occlusion by cell aggregates leading to water stress is the most accepted cause of the disease in plants infected with $X$. fastidiosa (Hopkins 1989). The degree of the occlusion might be related to the pathogen population within the xylem.

Hopkins (1985) suggests that colonization and pathogenicity of the PD strains of $X$. fastidiosa seem to be dependent on systemic movement within the xylem vessels. Virulence seems to be related to multiplication and movement in the host tissue, since avirulent or weakly virulent strains obtained after weekly serial transfers multiplied at a very slow rate and rarely moved from the inoculation point into the xylem vessels. In the present paper, inoculum of $X$. fastidiosa from the SP condition could not colonize the xylem vessels of either host as efficiently as FP. Colonization can be understood as the ability of the cells to adhere and multiply and, consequently, fill the vessels along the xylem. These results are in accordance to the hypothesis that successive passages could reduce bacterial virulence and affect the ability of colonization of the host (Hopkins 1985), as pointed out for other pathogenic bacteria (Masuzawa et al. 1994) and recently shown by Monteiro and associates (2001). In our experiments, we did not observe symptom development with the SP bacteria even 180 dai. Indeed, the population verified at this timepoint showed a decrease in relation to that at 120 dai, suggesting that the SP population is avirulent. It has been shown for other bacteria that mutations are associated with phenotypic changes after several passages in culture, including loss of virulence (Behr et al. 1999; Somerville et al. 2002). Nevertheless, the reason for the loss of virulence in $X$. fastidiosa remains unclear.

A comparison of the gene expression profiles in FP and SP conditions of $X$. fastidiosa revealed that only FP cells showed induction of genes related to pathogenicity, virulence, and adaptation, strengthening the idea that these genes could be related to the higher infectivity of bacteria in this condition, as determined by qPCR. In the assay using bacteria grown in planta, all the genes but msrA showed the same trend of higher expression in FP than in SP, although with a lower ratio as compared with the other experiments. The RT-PCR experiment in planta revealed no expression of $m s r \mathrm{~A}$ in either condition. The evaluation of gene expression 15 dai in the plant could be the reason explaining the absence of transcripts of $m s r \mathrm{~A}$, since this gene could be necessary in more advanced stages of colonization, and for this reason, a differential expression was observed after isolation of bacteria from symptomatic plants.

All seven genes detected in the microarray have very specific functions in pathogenicity. The msrA gene encodes a protein that catalyzes the reduction of methionine sulfoxide back to methionine (Weissbach et al. 2002). It is required for the functioning of adhesins in three mammalian pathogens, Streptococcus pneumoniae, Neisseria gonorrhaea, and Escherichia coli (Wizemann et al. 1996). More recently, the importance of this gene in the virulence of the plant pathogen Erwinia chrysanthemi was characterized. msrA mutants are more sensitive to oxidative stress, are incapable of systemic invasion, and ex- hibited reduced virulence on chicory leaves (Mohammed et al. 1999). The hypothesis to explain the alterations observed in these mutants is related to their incapacity to survive in plant tissue, leading to the decline of the population. The direct cause of this is thought to be oxidative damage caused by different factors, which, in the absence of the peptide methionine sulfoxide repair function, limits bacterial survival throughout the plant.

Thiol groups present in the bacterial cell surface could be mediating the adhesion of $X$. fastidiosa (Leite et al. 2002). The sulfur residue in its reduced form allows adhesion, and MsrA enzyme keeps these residues in this state (Lowther et al. 2000). Alternatively, the structures necessary for adhesion depend on some proteins that are sensitive to oxidative stress, and the role of MsrA is to maintain these proteins in their active form.

Another gene involved in adhesion of $X$. fastidiosa that was detected in the FP condition is fimA, similar to the one described for the plant pathogen $X$. hyacinthi (van Doorn et al. 2001). This protein is an adhesin of the type-IV fimbriae, similar to others found in numerous bacterial species that infect not only plants but also animals and humans (Ojanen-reuhs et al. 1997). They are considered key mediators of adhesion and motility, being an important virulence determinant. In $X$. campestris pv. vesicatoria, a plant pathogen, fim A, contributes to cellto-cell aggregation. Moreover, the fimA mutant poorly colonized the trichomes of tomato leaves, suggesting that adhesiveness to these plant structures involves FimA, similar to the type IV fimbriae of human pathogens (van Doorn et al. 2001). Therefore, the $X$. fastidiosa fimA can be involved in cell aggregation and the ability to form adherent colonies on surfaces.

Two other genes involved in the adhesion process in human pathogens were also highly expressed in $X$. fastidiosa grown under the FP condition. The uspA1 and $h s f$ genes show homology to uspA1 of $M$. catharralis and hsf of Haemophilus influenzae, respectively. A Blast search of the NCBI database showed homologies to several outer membrane proteins and adhesins important for attachment to host tissues (Cope et al 1999; Hoiczyk et al. 2000; Peak et al. 2000; St. Geme et al. 1996). The C-terminal regions of both adhesins in $X$. fastidiosa are similar and exhibit characteristics of autotransporter proteins.

In $M$. catharralis, UspA1 is structurally related to the UspA2 protein, although with different biological functions. UspA1 is essential for cell attachment, while UspA2 mediates serum resistance (Aebi et al. 1998; Lafontaine et al. 2000). No homologue of uspA2 was found in the $X$. fastidiosa genome. UspA1 has been shown to be essential for the attachment of $M$. catharralis to Chang conjuctival tissue in vitro (Lafontaine et al. 2000). Recently a uspA1 homologue, named $x a d \mathrm{~A}$, was characterized in Xanthomonas oryzae pv. oryzae (Ray et al. 2002). xadA mutants show reduced virulence and altered colony and lawn morphology. The XadA protein appears to be expressed in minimal medium but not in rich medium. As the authors point out, xylem sap is likely be more akin to minimal medium than to rich medium, suggesting that $x a d \mathrm{~A}$ is indeed being expressed in planta. Similarly, we observed that $X$. fastidiosa usp $\mathrm{A} 1$ is also differentially expressed in our growth conditions, in which freshly isolated bacteria were compared with bacteria grown in a very rich medium. Interestingly, the high expression of this gene in FP shows that one culture passage was not sufficient to turn off $u s p \mathrm{~A} 1$ expression.

The $h s f$ gene of $X$. fastidiosa is similar to the hsf and hia genes of $H$. influenzae. The $h s f$ gene product plays an important role in the process of respiratory tract colonization by $H$. influenzae type $\mathrm{b}$, while Hia mediates adhesion of the nontypeable $H$. influenzae. Hsf and Hia are $81 \%$ similar to each other and appear to recognize the same cell receptor; however, Hsf protein is associated with expression of short surface fibrils. In 
contrast, Hia has not been associated with fibril expression (St. Geme et al. 1996). These proteins could be part of a novel class of adhesins, like YadA of Yersinia spp. and UspA of $M$. catharralis (Hoiczyk et al. 2000). These adhesins follow the same architecture, forming a novel class of surface projections. The surface projections may be suitable to fulfill multiple functions, including the mediation of adherence to host cell surface structures, which may explain the wide occurrence of these adhesins among pathogens and free-living microorganisms. The expression of both adhesin genes in X. fastidiosa, together with msrA e fimA in FP, could produce an efficient adhesion mechanism, not only among cells but also with the surface of xylem vessels, resulting in a more efficient colonization. Based on bioinformatics analysis, these adhesins were recently suggested to be pathogenicity-related factors in X. fastidiosa (Bhattacharyya et al. 2002).

Scanning electron microscopy was recently used for studies on the biofilm formation in X. fastidiosa (Marques et al. 2002). The authors stress the necessity of identification of genes related to formation of the biofilm and their role in the infection and development of the disease. We show in this work that genes possibly related to disease development are involved in adhesion, which is an essential step for biofilm formation. Our results agree with the hypothesis that biofilm formation may be a key element in the pathogenicity of $X$. fastidiosa, resulting in an efficient capacity of colonization of the xylem vessels. Since the insect vector inoculates the bacteria inside the xylem vessel, a highly turbulent and negative pressure environment, an efficient adhesion mechanism could be essential for survival.

Other factors could also contribute with the more efficient colonization of FP cells, increasing the capacity of adaptation and competitiveness in the habitat to be colonized. Secretion of toxins and exoenzymes that depend on the type II secretion machinery could also be increased by a higher expression of components of this system, as observed for $x p s$ E. Production of proteins, like colicin $\mathrm{V}$, an antibacterial toxin produced by $E$. coli that acts against closely related sensitive bacteria (Havarstein et al. 1994), can also be an advantage factor for competition, since they could act against naturally found endophytes of the xylem. Studies suggest that colicins provide a competitive edge in nutrient-poor environments (Riley and Gordon 1999).

Moreover, some other gene products could act as detoxifying agents against a set of different drugs, represented here by AcrA and AcrB. Blast search using AcrA shows high similarity to other proteins present in several human and plant pathogens. It is thought to bring the outer and inner membranes closer and acts together with AcrB, a proton antiporter, composing a multidrug efflux system (Nikaido and Zgurskaya 2001). These different factors are likely to make $X$. fastidiosa an organism that is efficient for inhabiting the xylem vessels.

The genes that are possibly related to the higher colonization capacity in FP, identified as differentially expressed in the microarray experiment, can be a fraction of the genes actually expressed inside the plant. This is because the FP condition involves one step of growth in medium, which could turn off some of the pathogenicity genes in this initial condition. Moreover, by using the parameters defined in SAM, we detected only a percentage of the genes that could be observed using a less stringent setup but that could also increase the number of false positives. Still, we were able to detect some genes possibly involved in the colonization of the xylem vessels. Whiteley and associates (2001), using a fold change $>2$, detected few differentially expressed genes when evaluating biofilms of Pseudomonas aeruginosa. In a universe of 5,500 genes, only 34 were activated and 39 were repressed in biofilm populations representing approximately $1 \%$ of the genome. Similar results were found for Caenorhabditis elegans, where $1.5 \%$ of the ge- nome was differentially expressed in different developmental stages, growth conditions, or worm strains (Jiang et al. 2001).

Typical plant pathogens secrete effectors and enzymes used for the penetration and colonization of plant tissues (Barras et al. 1994; Lahaye and Bonas 2001). However, X. fastidiosa resembles some human bacterial pathogens whose pathogenicity depends on biofilm formation, leading to the occasional obstruction of the colonized area (Lafontaine et al. 2000; Murphy and Kirkham 2002).

Further studies aiming to produce mutants for the genes identified in this work are crucial in order to better characterize the mechanism utilized by the bacterium, especially in biofilm formation.

\section{MATERIALS AND METHODS}

\section{$X$. fastidiosa growth conditions.}

Cells of $X$. fastidiosa strain 9a5c were grown in PW broth (Davis et al. 1981) for 4 to 5 days, reaching $10^{8}$ colony forming units (CFU) per ml. The cells were collected by centrifugation and were resuspended in phosphate-buffered saline (PBS). A total volume of $40 \mu \mathrm{l}$ of the suspension was applied as a drop on the main shoot of periwinkle plants. We then pierced the spots where the drops had been deposited with a syringe needle, until the plant tissue absorbed all the suspension. Control plants were inoculated similarly with PBS free of bacteria. The plants were maintained in greenhouse conditions. Four months later, the plants showed symptoms such as stunting, short internodes, narrow limbs, small leaves, and chlorosis. Petioles and stems were aseptically ground in PBS, and the suspension was spread on PW medium. The first colonies were observed between 10 to 15 dai. This condition of $X$. fastidiosa was named first passage (FP). To obtain the $X$. fastidiosa after several passages (SP), the FP cells were transferred 46 times (once a week) to fresh PW plates.

\section{Pathogenicity assays.}

Plants of sweet orange cv. Pêra and periwinkle were grown in 21 pots containing a mixture of soil, sand, and manure $(2: 1: 1)$ and were maintained in a greenhouse under moderate water stress. Both FP and SP inoculum of $X$. fastidiosa were harvested and suspended in PBS at a final concentration of $10^{8}$ $\mathrm{CFU} / \mathrm{ml}$. A total volume of $40 \mu \mathrm{l}$ of the concentrated suspension of bacteria or of PBS as a control was inoculated in drops at the main shoot. The colonization in the plants was monitored by qPCR at 60, 120, and 180 dai.

\section{qPCR assays.}

Primers and the TaqMan probe (Applied Biosystems, Foster City, CA, U.S.A.) were developed for 5' nuclease PCR assays of $X$. fastidiosa (Oliveira et al. 2002). The 5'nuclease PCR with a fluoregenic probe was performed in a $25-\mu \mathrm{l}$ volume, using the TaqMan core PCR reagent kit (Applied Biosystems) as follows: $12.5 \mu \mathrm{l}$ TaqMan Universal PCR Master Mix (5 $\mu$ l of 10x TaqMan buffer, $10 \mathrm{mM}$ Tris [pH 8.3], 50 $\mathrm{mM} \mathrm{KCl}, 5 \mu \mathrm{l}$ of a deoxynucleoside triphosphate solution [2 $\mathrm{mM}$ each dATP, dCTP, and dGTP and $4 \mathrm{mM}$ dUTP], $0.5 \mathrm{U}$ of Amp Erase uracil N-glycosylase, and $0.25 \mathrm{U}$ of AmpliTaq Gold), $525 \mathrm{nM}$ of each primer, $500 \mathrm{nM}$ of the probe, $1 \mu \mathrm{lof}$ DNA solution (10 ng), and $6.87 \mu \mathrm{l}$ of water. The TaqMan buffer contains a passive reference dye, ROX, which is used to normalize for volume variations and to standardize the reaction (Heid et al. 1996). The amplifications were performed as described in the ABI PRISM 7700 User's Manual, using the recommended universal thermal cycler protocol as follows: all cycles began with $2 \mathrm{~min}$ at $50^{\circ} \mathrm{C}, 10 \mathrm{~min}$ at $95^{\circ} \mathrm{C}$, followed by 40 two-step cycles of $15 \mathrm{~s}$ at $95^{\circ} \mathrm{C}$ and $1 \mathrm{~min}$ at 
$60^{\circ} \mathrm{C}$. The determination of the fluorescent intensity of each dye, data acquisition, and data analysis were carried out in an ABI 7700 Prism Sequence Detector (Applied Biosystems). Fluorescent intensities were calculated using the Sequence Detector Software 1.6 application software (Applied Biosystems), as described by the manufacturer. Briefly, a normalized emission intensity of the reporter dye $\left(R_{n}\right)$ is defined for each reaction tube, and $\Delta R_{n}$, an indication of the signal magnitude generated by PCR, is calculated. The first statistically significant increase in $\Delta R_{n}$ for a given sample is denominated the $\mathrm{C}_{\mathrm{T}}$ value, which is the fractional cycle number of PCR, calculated as the average standard deviation of $R_{n}$ for the early cycles, in which no fluorescence is observed. Quantification of samples with unknown DNA amounts is accomplished by interpolation of their $C_{T}$ value obtained from a standard curve $\left(\mathrm{C}_{\mathrm{T}}\right.$ plotted against log target DNA) run simultaneously with the experimental samples. The standard curve was constructed according to the method previously described (Oliveira et al. 2002). Briefly, known amounts of $X$. fastidiosa and sweet orange total DNA were mixed to obtain a range of $1 \times 10^{0}$ to $1 \times 10^{5}$ copies of $X$. fastidiosa DNA per reaction mixture and then were used to make standard curves (i.e., $\mathrm{C}_{\mathrm{T}}$ values plotted against the logarithm of the DNA copy number). In all experiments, appropriate negative controls containing no template DNA were subjected to the same procedure to exclude or detect any possible contamination or carryover. Each sample was tested in triplicate, which was used for checking the standard deviation that was used for accepting or rejecting the measurement. The statistical analyses of the values obtained from the plants were carried, using the ANOVA procedure. The significance of the differences between the FP and SP treatments was verified by the Student $t$ test.

\section{Plant tissue extracts.}

For qPCR analyses, total DNA was extracted from $150 \mathrm{mg}$ of xylem-rich tissues from leaves (petiole and midrib) collected from seedlings of sweet orange and periwinkle inoculated with bacteria at both FP and SP conditions. Total DNA was extracted, based on modifications of the CTAB-Sarcosyl extraction method described previously (Machado et al. 1996). The DNA was diluted to $10 \mathrm{ng} / \mu \mathrm{l}$ and was stored at $-20^{\circ} \mathrm{C}$.

\section{Microarray construction.}

Specific pairs of primers were designed using Primer3 software (provided by S. Rozen and H. J. Skaletsky, Whitehead Institute, Cambridge, MA, U.S.A. and Howard Hughes Medical Institute, Chevy Chase, MD, U.S.A.) for the amplification of the ORFs found in the genome of $X$. fastidiosa strain 9a5c. We have simultaneously evaluated approximately 2,200 ORFs, including ORFs present in the pXf 51 plasmid. Many ORFs present in the 9a5c genome were actually duplications scattered throughout the chromosome or small ORFs encoding hypothetical proteins. These could not be efficiently and specifically amplified, due to their reduced size and chromosomal location (closely flanked by larger ORFs). Our estimation is that these analyses cover more than $90 \%$ of the most relevant ORFs present in the $X$. fastidiosa 9 a 5 c genome.

To maximize the homogeneity of the microarray hybridizations, amplified fragments had an average GC content around 50 to $60 \%$. Such PCR products were purified with the aid of the QiaQuick 96 PCR purification system (Qiagen, Valencia, CA, U.S.A.), were dried in a Savant speed-vac, were resuspended in $50 \%$ dimethyl sulfoxide at a final concentration of 100 to $200 \mathrm{ng} / \mu \mathrm{l}$, and were spotted onto CMT-GAPS silanecoated slides (Corning Glass Co., Corning, NY, U.S.A.), using an GMS 417 arrayer (Affimetrix Inc., Santa Clara, CA, U.S.A.) according to the manufacturer's instructions.

\section{RNA isolation and labeling.}

Cells from the FP and SP conditions were scraped from plates and were washed twice with diethylpyrocarbonate (DEPC)-treated water. Total RNA was isolated as described by V. Rhodius on the University of California at San Francisco website. Further details are available on the Centro APTA Citros website.

RNA obtained from $X$. fastidiosa cells was labeled by reverse transcription with either $\mathrm{Cy} 3$ or $\mathrm{Cy} 5$ (both labeling for each condition). Briefly, $30 \mu \mathrm{g}$ of total bacterial RNA was mixed with $16 \mu \mathrm{g}$ of random hexamers (Gibco BRL, Gaithersburg, MD, U.S.A.) in a $30-\mu l$ final volume. Annealing was accomplished by incubation for $2 \mathrm{~min}$ at $75^{\circ} \mathrm{C}, 2 \mathrm{~min}$ at $55^{\circ} \mathrm{C}, 2 \mathrm{~min}$ at $45^{\circ} \mathrm{C}$, $2 \mathrm{~min}$ at $37^{\circ} \mathrm{C}$, and $2 \mathrm{~min}$ at $22^{\circ} \mathrm{C}$, followed by addition of $6 \mu \mathrm{l}$ of SuperScript II reaction buffer (Gibco BRL), $3 \mu \mathrm{l}$ of $0.1 \mathrm{M}$ of dithiothreitol, $1 \mu \mathrm{l}$ dNTP mix (10 mM dATP, $10 \mathrm{mM}$ dGTP, 10 $\mathrm{mM}$ dTTP, $5 \mathrm{mM}$ dCTP), $2 \mu \mathrm{l}$ of $1.0 \mathrm{mM} \mathrm{Cy3-} \mathrm{or} \mathrm{Cy5-labeled}$ dCTP (Amersham Biosciences, Little Chalfont, U.K.), and $2 \mu \mathrm{l}$ of SuperScript II reverse transcriptase $(200 \mathrm{U} / \mu \mathrm{l})$ (Gibco BRL) to the reaction. Reactions without SuperScript, using Klenow, were done in parallel to verify presence of contaminating DNA. The cDNA synthesis was carried at $42^{\circ} \mathrm{C}$ for $2 \mathrm{~h}$. After labeling, the RNA was hydrolyzed in a $0.1 \mathrm{~N} \mathrm{NaOH}$ treatment and was neutralized by the addition of $0.1 \mathrm{~N} \mathrm{HCl}$. The labeled cDNA was diluted to $500 \mu \mathrm{l}$ with Tris-EDTA, purified, and concentrated using a Microcon-30 (Amicon, Bedford, MA, U.S.A.) to $10 \mu \mathrm{l}$.

\section{Hybridization and analysis.}

Arrays were hybridized overnight $\left(42^{\circ} \mathrm{C}\right)$ in a GeneTac hybridization station (Genomic Solutions, Inc., Ann Arbor, MI, U.S.A.), in $6 \times \mathrm{SSC}(1 \times \mathrm{SSC}$ is $0.15 \mathrm{M} \mathrm{NaCl}$ plus $0.015 \mathrm{M}$ sodium citrate), $5 \times$ Denhardt's solution, $0.25 \mathrm{mg}$ of sheared salmon sperm DNA per ml, $0.5 \%$ sodium dodecyl sulfate (SDS), and a mixture of the two labeled cDNA samples. After hybridization, slides were washed twice $\left(42^{\circ} \mathrm{C}\right)$ in $0.5 \times \mathrm{SSC}$ and $0.01 \%$ SDS, followed by two washes in $0.06 \times$ SSC and $0.01 \%$ SDS, and two final washes in $0.06 \times$ SSC. All washing steps consisted of $1 \mathrm{~min}$ of flow, followed by $5 \mathrm{~min}$ of incubation. Slides were then snap-dried and subjected to fluorescence detection with an GMS 418 Array Scanner (Affimetrix Inc.). Images were analyzed with Affymetrix Jaguar v. 2.0, using the easy threshold and variable circle size algorithm. Normalization between the intensities in the two channels was achieved with the Jaguar All Spots option. Three independent experiments were performed with nine individual comparisons. These data were consolidated into a GATC database with Affymetrix MicroDB v. 2.0, and the data was used for final statistical analysis with SAM, a statistical technique developed for finding significant genes in a set of microarray experiments (Tusher et al. 2001) available on Stanford University's SAM webpage.

\section{RT-PCR.}

The same total RNA used for the microarrays was reversetranscribed with SuperScript II (Invitrogen, Carlsbad, CA, U.S.A.) by using $1 \mu \mathrm{g}$ of the R-specific primer for each of the analyzed genes (Table 3). The RNAs were normalized, using ribosomal RNA content. We carried analyses for all seven pathogenicity genes (fim A, msrA, uspA1, hsf, cvaC, acrA, and $x p s \mathrm{E}$ ) that were amplified with specific primers (Table 3). A 25 $\mu 1$ master mix contained the following components: $2.5 \mu \mathrm{M}$ dNTP, Taq polymerase reaction buffer (Invitrogen), $2.5 \mathrm{mM}$ $\mathrm{MgCl}_{2}, 100 \mathrm{ng}$ of specific primers, 2.5 units of Taq DNA polymerase, and $2.5 \mu \mathrm{l}$ of first-strand cDNA template. The PCR cycle profile was $94^{\circ} \mathrm{C}$ for 3 min for initial denaturation, followed by 25 cycles of $94^{\circ} \mathrm{C}$ for $1 \mathrm{~min}, 50^{\circ} \mathrm{C}$ for $1 \mathrm{~min}$, and 
Table 3. The nucleotide sequences of the primers used for reverse transcriptase-polymerase chain reaction

\begin{tabular}{|c|c|c|}
\hline Gene name & Primers sequence & Fragment size (in base pairs) \\
\hline \multirow[t]{2}{*}{ fimA } & F-5' CCCTCGAGCCAAAATTATGTCGCCAGA 3' & 350 \\
\hline & R—5' CACTCGAGGTGACGGTGGAGGAGCAG 3' & \\
\hline \multirow[t]{2}{*}{$m s r A$} & F-5' AATCTCGAGTGGGACGTAGTGAAC 3' & 498 \\
\hline & R—5' AAGCTCGAGCCGGATGGAGTA 3' & \\
\hline \multirow[t]{2}{*}{ uspA1 } & F-5' AACTCGAGAGCAGGCCGCCGGTGATAGCAGTA 3' & 1,122 \\
\hline & $\mathrm{R}-5^{\prime}$ AGACGCTCGAGCCCCCGCCGCAAGAT 3' & \\
\hline \multirow[t]{2}{*}{$h s f$} & F-5' CGCTCGAGGGGTCTTTGTATGT 3' & 647 \\
\hline & R-5' GGCTCGAGACGCTGTGAGGTTC 3' & \\
\hline \multirow[t]{2}{*}{$c v a C$} & F-5' GTCTCGAGGCGACCTTGCTAC 3' & 194 \\
\hline & R-5' AGCAGCCTCGAGACCACAGATAC 3' & \\
\hline \multirow[t]{2}{*}{$\operatorname{acr} A$} & F-5' CTCTCGAGCACGCGTGGCTGGAATA 3' & 919 \\
\hline & R—5' AGCTCGAGCGCCTTCTTTGACTTTT 3' & \\
\hline \multirow[t]{2}{*}{ xpsE } & F-5' GTCTCGAGTTGTTGGCGGAAGTATGAA 3' & 1,101 \\
\hline & R—5' CCCTCGAGCCAGTGACCAGCAAAATG 3' & \\
\hline
\end{tabular}

$72^{\circ} \mathrm{C}$ for $1 \mathrm{~min}$. PCR products were run on agarose gels, quantified densitometrically using EagleSight software v. 3.2 (Stratagene, La Jolla, CA, U.S.A.).

\section{Plant inoculation and cell harvest.}

Citrus sinensis plants propagated by seeds and grown in an insect-proof greenhouse were used for inoculation of $X$. fastidiosa $9 \mathrm{a} 5 \mathrm{c}$ from either FP or SP conditions, in order to evaluate the gene expression of all seven pathogenicity genes detected in microarray. The inoculation was performed as described above for the pathogenicity assays but using several inoculation points. The plants were maintained in a growth chamber at $28^{\circ} \mathrm{C}$ with a photoperiod of $12 \mathrm{~h}$ light and $12 \mathrm{~h}$ dark. Three plants were inoculated with FP and three others with SP. After 15 days, a period of time sufficient for the colonization of the vessels (Almeida et al. 2001), the leaf petioles and midribs were excised from all the plants. For extraction of cells from the xylem, the bacteria were forced from the petioles or stems, using a DEPC-treated water wash using a syringe attached to a rubber tube. The resultant bacterial cell suspension was centrifuged at $4,000 \times g$ for $10 \mathrm{~min}$ at $4^{\circ} \mathrm{C}$, and total RNA was extracted using TRIZOL reagent (Invitrogen).

The RT-PCR was performed as described above. However, due to the low RNA concentration, we performed 35 amplification cycles. Reactions without SuperScript II were done in parallel to rule out the possibility of amplification from contaminating DNA.

\section{ACKNOWLEDGMENTS}

This work was supported by research grants from Fundação de Amparo à Pesquisa do Estado de São Paulo (FAPESP) (process numbers 99/04266-6 and 98/04266-6). M. A. Takita is a FAPESP Postdoctoral Fellow.

\section{LITERATURE CITED}

Aebi, C., Lafontaine, E. R., Cope, L. D., Latimer, J. L., Lumbley, S. R., McCracken, G. H., Jr., and Hansen, E. J. 1998. Phenotypic effect of isogenic uspA1 and uspA2 mutations on Moraxella catarrhalis 035E. Infect. Immun. 66:3113-3119.

Almeida, R. P. P., Pereira, E. F., Purcell, A. H., and Lopes, J. R. S. 2001. Multiplication and movement of a citrus strain of Xylella fastidiosa within sweet orange. Plant Dis. 85:382-386.

Barnard, E. L., Ash E. C., Hopkins D. L., and McGovern R. J. 1998. Distribution of Xylella fastidiosa in oaks in Florida and its association with growth decline in Quercus laevis. Plant Dis. 82:569-572.

Barras, F., Van Gijsegem, F., and Chatterjee, A. K. 1994. Extracellular enzymes and pathogenesis of soft-rot Erwinia. Annu. Rev. Phytopathol. 32:201-234.

Behr, M. A., Wilson, M. A., Gill, W. P., Salamon, H., Schoolnik, G. K., Rane, S., and Small, P. M. 1999. Comparative genomics of BCG vaccines by whole-genome DNA microarray. Science. 284:1520-1523.

Bhattacharyya, A., Stilwagen, S., Ivanova, N., D’Souza, M., Bernal, A.,
Lykidis, A., Kapatral, V., Anderson, I., Larsen, N., Los, T., Reznik, G., Selkov, E., Jr., Walunas, T. L., Feil, H., Feil, W. S., Purcell, A., Lassez, J.-L., Hawkins, T. L., Haselkorn, R., Overbeek, R., Predki, P. F., and Kyrpides, N. C. 2002. Whole-genome comparative analysis of three phytopathogenic Xylella fastidiosa strains. Proc. Natl. Acad. Sci. U.S.A. 99:12403-12408.

Chagas, C. M., Rosseti, V., and Beretta, M. J. G. 1992. Electron microscopy studies of a xylem-limited bacterium in sweet orange affected with citrus variegated chlorosis disease in Brazil. J. Phytopathol. 134:306-312.

Cope, L., Lafontaine, E. R., Slaughter, C. A., Hasemann, C. A., Jr., Aebi, C., Henderson, F. W., McCracken, G. H., Jr., and Hansen, E. J. 1999. Characterization of the Moraxella catarrhalis uspA1 and uspA2 genes and their encoded products. J. Bacteriol. 181:4026-4034.

Costa de Oliveira, R., Yanai, G. M., Muto, N. H., Leite, D. B., Souza, A. A., Coletta-Filho, H. D., Machado, M. A., and Nunes, L. R. 2002. Competitive hybridization on spotted microarray as a tool to conduct comparative genomics analyses of Xylella fastidiosa strains. FEMS (Fed. Eur. Microbiol. Soc.) Microbiol. Lett. 216:15-21.

Davis, M.J., Purcell, A. H., and Thomson, S. V. 1981. Isolation media for the Pierce's disease bacterium. Phytopathology 73:1510-1515.

Havarstein, L. S., Holo, H., and Nes, I. F. 1994. The leader peptide of colicin V shares consensus sequences with leader peptides that are common among peptide bacteriocins produced by gram-positive bacteria. Microbiology 140:2383-2389.

Heid, C. A., Stevens, J., Livak, K. J., and Willians, P. M. 1996. Real time quantitative PCR. Genome Res. 6:986-994.

Hoiczyk, E., Roggenkamp, A., Reichenbecher, M., Lupas, A., and Heesemann, J. 2000. Structure and sequence analysis of Yersinia YadA and Moraxella UspAs reveal a novel class of adhesins. EMBO (Eur. Mol. Biol. Organ.) J. 19:5989-5999.

Hopkins, D. L. 1985. Physiological and pathological characteristics of virulent and avirulent strains of the bacterium that causes Pierce's disease of grapevines. Phytopathology. 75:713-717.

Hopkins, D. L. 1989. Xylella fastidiosa: A xylem-limited bacterial pathogen of plants. Ann. Rev. Phytopathol. 27:271-290.

Hu, W. N., Band, R. N., and Kopachik, W. 1991. Virulence-related protein synthesis in Naegleria fowleri. Infect Immun. 59:4278-4282.

Jiang, M., Ryu, J., Kiraly, M., Duke, K., Reinke, V., Kim, S. K. 2001. Genome-wide analysis of developmental and sex-regulated gene expression profiles in Caenorhabditis elegans. Proc. Natl. Acad. Sci. U.S.A.:98:218-223.

Lafontaine, E. R., Cope, L. D., Aebi, C., Latimer, J. L., McCracken, G. H., Jr., and Hansen, E. J. 2000. The UspA1 protein and a second type of UspA2 protein mediate adherence of Moraxella catarrhalis to human epithelial cells in vitro. J. Bacteriol. 182:1364-1373.

Lahaye, T., and Bonas, U. 2001. Molecular secrets of bacterial type III effector proteins. Trends Plant Sci. 6:479-485.

Leite, B., Ishida, M. L., Alves, E., Carrer, H., Pascholati, S. F., and Kitajima, E. W. 2002. Genomics and X-ray microanalysis indicate that $\mathrm{Ca}^{2+}$ and thiols mediate the aggregation and adhesion of Xylella fastidiosa. Braz. J. Med. Biol. Res. 35, 645-650.

Levine, J. F., Dykstra, M. J., Nicholson, W. L., Walker, R. L., Massey, G., and Barnes, H. J. 1990. Attenuation of Borrelia anserina by serial passage in liquid medium. Res. Vet. Sci. 48, 64-69.

Lima, J. E. O., Miranda V. S., Hartung J. S., Brlansky R. H., Coutinho A., Roberto S. R., and Carlos E. F. 1998. Coffee leaf scorch bacterium: Axenic culture, pathogenicity, and comparison with Xylella fastidiosa of citrus. Plant Dis. 82:94-97.

Lowther, W. T., Brot, N., Weissbach, H., Honek, J. F. and Matthews, B. W. 2000. Thiol-disulfide exchange is involved in the catalytic mecha- 
nism of peptide methionine sulfoxide reductase. Proc. Natl. Acad. Sci. U.S.A. 97:6463-6468.

Machado, E. C., Quaggio, J. A., Lagôa, A. M. M. A., Ticelli, M., Furlani, P. R. 1994. Trocas gasosas e relações hídricas em laranjeiras com clorose variegada dos citros. R. Bras. Fisiol. Veg. 6:53-57.

Machado, M. A., Coletta-Filho, H. D., Targon, M. L. P. N., and Pompeu, J., Jr., 1996. Genetic relationship of Mediterranean mandarins (C. deliciosa Tenore) using RAPD markers. Euphytica 92:321-326.

Machado, M. A., Souza, A. A., Coletta-Filho, H. D., Kuramae, E. E., and Takita, M. A. 2001. Genome and pathogenicity of Xylella fastidiosa. Mol. Biol. Today 2:33-43.

Marques L. L. R., Ceri H., Manfio G. P., Reid D. M., and Olson M. E. 2002. Characterization of biofilm formation by Xylella fastidiosa in vitro. Plant Dis. 86:633-638.

Masuzawa, T., Kurita, T., Kawabata, H., and Yanagihara, Y. 1994. Relationship between infectivity and OspC expression in Lyme disease borrelia. FEMS (Fed. Eur. Microbiol. Soc.) Microbiol. Lett. 123, 319324.

McCutchan, J. A., Levine, S., and Braude, A. I. 1976. Influence of colony type on susceptibility of gonococci to killing by human serum. J. Immunol. 116:1652-1655.

Mohammed, E. H., Chambost, J. P., Expert, D., Gijsegem, V. F., and Barras, F. 1999. The minimal gene set member msrA, encoding peptide methionine sulfoxide reductase, is a virulence determinant of the plant pathogen Erwinia chrysanthemi. Proc. Natl. Acad. Sci. U.S.A. 96:887-892

Monteiro, P. B., Renaudin, J., Jagoueix-Eveillard, S., Ayres, A. J., Garnier, M., and Bové, J. M. 2001. Catharanthus roseus, an experimental host plant for the citrus strain of Xylella fastidiosa Plant Dis. 85:246-251.

Murphy, T. F., and Kirkham, C. 2002. Biofilm formation by nontypeable Haemophilus influenzae: Strain variability, outer membrane antigen expression and role of pili. BMC Microbiol. 2:1-8.

Nikaido, H., and Zgurskaya, H. I. 2001. AcrAB and related multidrug efflux pumps of Escherichia coli. J. Mol. Microbiol. Biotechnol. 3:215-218.

Ojanen-reuhs, T., Kalkkinen, N., Westerlund-Wikström, B., van-Door, J. Haahtela, K., Nurmiaho-Lassila, E.-L., Wengelnik, K., Bonas, U., and Korhonen, T. K. 1997. Characterization of the fimA gene encoding bundle-forming fimbriae of the plant pathogen Xanthomonas campestris pv. vesicatoria. J. Bacteriol. 179, 1280-1290.

Oliveira, A. C., Vallim, M. A., Semighini, C. P., Araújo, W. L., Goldman, G. H., and Machado, M. A. 2002. Quantification of Xylella fastidiosa from citrus trees by real-time polymerase chain reaction assay PCR. Phytopathology 92:1048-1054.

Peak, I. R., Srikhanta, Y., Dieckelmann, M., Moxon, E. R., and Jennings, M. P. 2000. FEMS (Fed. Eur. Microbiol. Soc.) Immunol. Med Microbiol. 28:329-334.

Purcell, A. H., and Hopkins D. L.. 1996. Fastidiuos xylem-limited bacterial plant pathogens. Ann. Rev. Phytopathol. 34:131-151.

Ray, S. K., Rajeshwari, R., Sharma, Y., and Sonti, R. V. 2002. A high-molecular-weight outer membrane protein of Xanthomonas oryzae pv. oryzae exhibits similarity to non-fimbrial adhesins of animal pathogenic bacterial and is required for optimum virulence. Mol. Microbiol. 46:637-647.

Riley, M. A., and Gordon, D. M. 1999. The ecological role of bacteriocins in bacterial competition. Trends Microbiol. 7:129-133.

Simpson, A. J. G., Reinach F. C., Arruda P., Abreu F. A., Acencio M. Alvarenga R., Alves L. M. C., Araya J. E., Baia G. S., Baptista, C. S., Barros, M. H., Bonaccorsi, E. D., Bordin, S., Bové, J. M., Briones, M. R. S., Bueno, M. R. P., Camargo, A. A., Camargo, L. E. A., Carraro, D. M., Carrer, H., Colauto, N. B., Colombo, C., Costa, F. F., Costa, M. C. R., Costa-Neto, C. M., Coutinho, L. L., Cristofani, M., Dias-Neto, E., Docena, C., El-Dorry, H., Facincani, A. P., Ferreira, A. J. S., Ferreira, V. C. A., Ferro, J. A., Fraga, J. S., França, S. C., Franco, M. C., Frohme, M., Furlan, L. R., Garnier, M., Goldman, G. H., Goldman, M. H. S., Gomes, S. L., Gruber, A., Ho, P. L., Hoheisel, J. D., Junqueira,
M. L., Kemper, E. L., Kitajima, J. P., Krieger, J. E., Kuramae, E. E., Laigret, F., Lambais, M. R., Leite, L. C. C., Lemos, E. G. M., Lemos, M. V. F., Lopes, S. A., Lopes, C. R.,. Machado, J. A, Machado, M. A., Madeira, A. M. B. N., Madeira, H. M. F., Marino, C. L., Marques, M. V., Martins, E. A. L., Martins, E. M. F., Matsukuma, A. Y., Menck, C. F. M., Miracca, E. C., Miyaki, C. Y., Monteiro-Vitorello, C. B., Moon, D. H., Nagai, M. A., Nascimento, A. L. T. O., Netto L. E. S, Nhani, A., Jr., Nobrega, F. G., Nunes, L. R., Oliveira, M. A., de Oliveira, M. C., de Oliveira, R. C., Palmieri, D. A., Paris, A., Peixoto, B. R., Pereira, G. A. G., Pereira, H. A., Jr., Pesquero, J. B., Quaggio, R. B., Roberto, P. G., Rodrigues, V., Rosa, A. . de M., de Rosa, V. E., Jr., de Sá, R. G., Santelli, R. V., Sawasaki, H. E.,. da Silva, A. C. R, da Silva A. M., da Silva, F. R., da Silva, W. A., Jr., da Silveira, J. F., Silvestri, M. L. Z., Siqueira, W. J., de Souza, A. A., de Souza, A. P., Terenzi, M. F., Truffi, D., Tsai, S. M., Tsuhako, M. H., Vallada, H., Van Sluys, M. A., Verjovski-Almeida, S., Vettore, A. L., Zago, M. A., Zatz, M., Meidanis J., and Setubal J. C. 2000. The genome sequence of the plant pathogen Xylella fastidiosa. Nature 406:151-159.

Somerville, G. A., Beres, S. B., Fitzgerald, J. S., DeLeo, F. R., Cole, R. L., Hoff, J. S., and Musser, J. M. 2002. In vitro serial passage of Staphylococcus aureus: Changes in physiology, virulence factor, and agr nucleotide sequence. J. Bacteriol. 184:1430-1437.

St. Geme, J. W., Cutter, D., and Barenkamp, S. J. 1996. Characterization of the genetic locus encoding Haemophilus influenzae type b surface fibrils. J. Bacteriol. 178, 6281-6287.

Tusher, V. G., Tibshirani, R., and Chu, G. 2001. Significance analysis of microarrays applied to the ionizing radiation response. Proc. Natl. Acad. Sci. U.S.A. 98:5116-5121.

van Doorn, J., Hollinger, T. C., and Oudega, B. 2001. Analysis of the type IV fimbrial-subunit gene fimA of Xanthomonas hyacinthi: Application in PCR-mediated detection of yellow disease in hyacinths. Appl. Environ. Microbiol. 67:558-607.

Weissbach, H., Etienne, F., Hoshi, T., Heinemann, S. H., Lowther, W. T., Matthew, B., St. John, G. Nathan, C., and Brot, N. 2002. Peptide methionine sulfoxide reductase: Structure, mechanism of action, and biological function. Arch. Biochem. Biophys. 397:172-178.

Whiteley, M., Bangera, M. G., Bumgarner, R. E., Parsek, M. R., Teitzei, G. M., Lory, S., Greenberg, E. P. 2001. Gene expression in Pseudomonas aeruginosa biofilms. Nature 413:860-864.

Wizemann, T. M., Moskovitz, J., Pearce, B. J., Cundell, D., Arvidson, C. G., So, M., Weissbach, H., Brot, N., and Masure, H. R. 1996. Peptide methionine sulfoxide reductase contributes to the maintenance of adhesins in three major pathogens. Proc. Natl. Acad. Sci. U.S.A. 93:7985-7990.

\section{AUTHOR-RECOMMENDED INTERNET RESOURCES}

Agronomical and Environmental Genomes (AEG), an ONSA program, Xylella database: aeg.lbi.ic.unicamp.br/xf

Centro APTA Citros Sylvio Moreira $X$. fastidiosa webpage: www. centrodecitricultura.br/miame_xf.htm

Organization for Nucleotide Sequencing and Analysis (ONSA); onsona.lbi.ic.unicamp.br/world/xf-grape/

Stanford University Department of Statistics Significant Analysis of Microarrays webpage: www-stat.stanford.edu/ tibs/SAM/index.html

United States Department of Energy's Genome Institute microbial genomics webpage: www.jgi.doe.gov/JGI_microbial/html

University of California at San Francisco Department of Biochemistry and Biophysics microarrays and software website: www.microarrays. org/pdfs/Total_RNA_from_Ecoli.pdf

Washington University in St. Louis database of protein families (Pfam): pfam.wustl.edu/

The Whitehead Institute and Massachusetts Institute of Technology Primer3 software: www-genome.wi.mit.edu/genome_software/other/ primer3.html 


\section{Erratum, Vol. 16, No. 10, 2003}

A literature citation in the article by de Souza et al. was published incorrectly. The article was cited at the top of the second column on page 871 . Mohammed et al. 1999 should be Hassouni et al. 1999 and the citation should be as follows.

Hassouni, M. E., Chambost, J. P., Expert, D., Van Gijsegem, F., and Barras, F. 1999. The minimal gene set member msrA, encoding peptide methionine sulfoxide reductase, is a virulence determinant of the plant pathogen Erwinia chrysanthemi. Proc. Natl. Acad. Sci. U.S.A. 96:887-892. 